\title{
Europe as a Beacon of Hope? 1
}

\section{Traditional European trends in human rights}

Critique of the peno-legal development in Europe should not be viewed as critique of European unification - this is a common misperception. Critique means taking the particularities of penal law in the European unification process into consideration. The guarantee of human rights is especially relevant in penal law and requires particular consideration when constructing a European legal space. The debate on a European penal law belongs center stage in the discussions on European integration. Currently, penal law is being relegated to the background in the form of a failed administrative penal law solely to protect economic interests.

The economy is the absolute priority in the European unification process, that is, the economies of the individual states. The normative postulates of the treaty histories of the EU are oriented on this. The parallel development of domestic markets and domestic legal spaces was delimited and led by the treaties of Maastricht (1992), Amsterdam (1997), Nice (2001), and most recently Lisbon (2007). The motto of the European unification process is: From the identity of the individual states to the integration of Europe! Currently, 27 states have come together under the auspices of the treaties of the European Union (TFEU and TEU). Further candidates are waiting in the wings. Is it then not necessary to involve the penal law of the European nation-states in the integration in order to "communitize" it? Why should that be wrong, integration proponents might ask. Is Europe not the guarantor for the protection of basic rights and freedom? Is that not the legacy of European Enlightenment and isn't the European Convention on Human Rights called on to limit penal law with its principles?

Indeed, universal human rights and freedom are the reference points of European Enlightenment. In this empirical tradition, and in the European tradition, human dignity and the tradition of rule of law-based criminal law arises. Linked to this are the Europeanwide expectations for a material, rule of law-based criminal law which is oriented on human rights.

\section{European Human Rights Convention (ECHR): Reaction to massive experiences of injustice}

After the terror of the national-socialist state, Europe felt a new sense of hope with the ECHR. In the post-war era, the ECHR was limited in its protective function for basic and civil rights to national penal law. Out of this, important guiding principles for the development of material rule of law-based peno-legal orders can be gathered. These

1 The references further quoted can be found in Albrecht, P.-A., Der Weg in die Sicherheitsgesellschaft, Auf der Suche nach staatskritischen Absolutheitsregeln, 2010 (Securitized Societies, The Rule of law: History of a free fall, 2011). 
were important for the legal development of most of the European states after World War II. They are the

- principles of penal legality (Art. 7 ECHR) and the

- principles of judicial legal protection through judicial control of all punishments (Art. 5 ECHR)

- in a fair trial (Art. 6 ECHR).

These guiding principles alone - which are certainly linked to the European Enlightenment - ensure a certain and thus predictable penal law as well as judicially controlled code of criminal procedure: The citizen is thereby an autonomous subject in the law, not the object of state use of power. As a reaction to massive experiences of injustice, the states of the Council of Europe passed those legal principles which are intended to bind every use of state power and every peno-legal order to the guarantees of legality and basic rights. The principles of the Convention on Human Rights mark the beginning of a period which the European integration linked with the hope of the limitation of authoritarian punishments and the unfurling of individual freedom. In Germany especially those who see the destruction of the rule-of-law state in these excessive demands of national prevention are led by these intentions.

\section{The EU's integration movement: Erosion of peno-legal principles}

The hope of a European penal law developing from the principles of the ECHR was if it ever truly existed - quickly buried by the integration movement of the European Community. Under the political battle cry of a European economic integration at any price, the areas of basic rights which drew the least amount of public resistance - homeland security and penal law - were immediately drawn into the maelstrom of "communitization" (both the first as well as the third pillar). In penal law, the supranational European Union stepped up alongside the nation-states. For this, however, an appropriate universally justified and applicable standard for penal and criminal procedural law should have been required.

Such a standard is lacking in the inter-governmental cooperation in the area of domestic and security policy even today. "European penal law" is not a legal term. It does not represent an effective legal order directly through institutions and instances of an empirically understandable criminal justice system. Where there is no monopolized use of force by the state, there is no penal law. Lacking an appropriate explicit competency for law-making in the European Union, "European penal law" is technically non-existent. There is, at least ostensibly, a consensus that the sovereignty of the nation-state law-makers must remain untouched regarding penal law. ${ }^{2}$ This is due to the varying cultural backgrounds and historical traditions which are reflected in the crimino-legal

2 Cf. Tiedemann, K., Europäisches Gemeinschaftsrecht und Strafrecht, NJW 1993, p. 23; Delmas-Marty, M., Union Européenne et droit pénal, Cahiers de droit européen, 1997, p. $607 \mathrm{ff}$. (608), Schulz, J., Europäisches Strafrecht, in: Rengeling (Ed.) Europäisierung des Rechts, 1996, p. 183 ff. (189). 
orders of the individual member states. ${ }^{3}$ In light of the third pillar which was introduced by the Maastricht Treaty for judicial and police cooperation, it was made clear that the sovereignty of the member states in regards to the "maintenance of public order" and the "protection of homeland security" remained untouched. After the further expansion of the third pillar in the Treaty of Amsterdam, Article 33 TEU emphasized the continuing responsibility of the member states for domestic and legal matters.

Through both treaties, penal law was drawn more and more into the focus of European integration. Both treaties were the cornerstones of the European framework for the penal law of each of the member states. In the context of the framework and its legal mechanisms, however, the primacy of national penal law begins to crumble. National penal law and European law are contingent on each other. In large part, both are pressed into supranational forms. ${ }^{4}$

\section{Contingency and blurring of boundaries in intra-national law}

In $1998^{5}$ and in 2001, ${ }^{6}$ Stefan Braum and I described this form of legal development in the Kritischen Vierteljahresschrift (Critical Quarterly). The step from the economic community to European political integration with common domestic and legal policy goals had already been taken in the treaties of Maastricht, Amsterdam, and Nice. The Treaty of Lisbon considerably expanded the competency in the context of judicial cooperation in criminal matters and police cooperation. Now it is possible to pass "minimal regulations" in the area of penal and criminal procedural law, "to the extent necessary to facilitate mutual recognition of judgments and judicial decisions and police and judicial cooperation in criminal matters having a cross-border dimension" (Art. 82 Para. 2 TFEU). In addition to this, the existing competency of the EU for the legal harmonization in the area of penal law was expanded. The EU was given the authority to use guidelines to "establish minimum rules concerning the definition of criminal offences and sanctions in the areas of particularly serious crime with a cross-border dimension resulting from the nature or impact of such offences or from a special need to combat them on a common basis" (Art. 83 Para. 1 AEUV). With an emergency brake mechanism, a member of the Council who is of the opinion that a directive draft infringes on "fundamental aspects of its criminal justice system" can request that the issue be referred to the European Council (Art. 82 Para. 3 and Art. 83 Para. 3 TFEU).

In these treaties, a community authority was stated that was subject to political will in the matter of the cooperation of the member states in criminal matters, and with the

3 Here cf. the argument of Weigend, T., Strafrecht durch internationale Vereinbarungen - Verlust an nationaler Strafrechtskultur, ZStW 105 (1993), p. 774 (786ff.); at the begin of the $1980 \mathrm{~s}$, this was already mentioned by Jung, H./Schroth, H.J., Das Strafrecht als Gegenstand der Rechtsangleichung in Europa, GA 1983, p. 241 (242).

4 Braum, S., Das Prinzip der gegenseitigen Anerkennung - Historische Grundlagen und Perspektiven europäischer Strafrechtsentwicklung, GA 2005, p. $681 \mathrm{ff}$.

5 Albrecht, P.-A./Braum, S., Defizite europäischer Strafrechtsentwicklung, KritV 1998, p. $460 \mathrm{ff}$.

6 Albrecht, P.-A./Braum, S., Kontingentes „Europäisches Strafrecht“ in actio: Schwerpunkte, Konturen, Defizite, KritV 2001, p. $312 \mathrm{ff}$. 
entry into force of the Lisbon Treaty this can be implemented as community law by majority decisions.

Not only the treaties, but also the European Court of Justice (ECJ) and the peno-legal directive practice of the community (first pillar) quickly make it clear that the goal of the supranational and inter-state level is to create peno-legal access that is as complete as possible. At the supranational level, as well, the justification for the directives is: preventive, effective, and security-optimizing. They are "policy open" and at the same time avoid the key peno-legal principles of penal legality - the principle of guilt and the principle of proportionality. ${ }^{7}$

The ECJ has an instrumental understanding of penal law, far from basic rights and a subject understanding of those subject to the law. This may primarily be the case because the ECJ concentrates on questions of legal competency. According to Art. 6 Para. 2 TEU, the Union may have the responsibility to respect the basic rights granted in the ECHR, but the ECJ is only responsible for actions by the EU organs which are relevant to basic rights, and questions of institutional basic rights rarely arise. Unfortunately, the protection of basic rights thereby remains very rudimentary from the perspective of the ECJ, despite the principle of referral.

In the course of the discussion on competency amongst the EU organs and national parliaments, rule-of-law standards are often left by the wayside. Or they are referred back and forth between EU organs and national parliaments. A sad example of this is the arrest warrant of the European Union. The framework decision (third pillar) refrains from the previously valid principle of "dual criminality." Up until the present, this was the basis for extradition requests of foreign states regarding German citizens. Instead, one agreed upon the principle of "mutual recognition." Through this, a new principle in EU law in Europe was created, that is, the principle of "maximum punitivity." After the Federal Constitutional Court declared the first version of the German law on the EU arrest warrant to be invalid because the basic principle of care for the state's own citizens had not been recognized by the law-makers, I had the opportunity to state my position on the new legislative draft before the legal committee of the German Bundestag. Despite the obvious shortcomings of the second attempt by the law-makers, the representatives of the German Bundestag passed the second draft. Members of the legal committee were clearly uneasy. Representative Jerzy Montag (Green Party) asked me whether I could even recommend that the German Bundestag should withhold its acceptance of this second legislative draft. The representatives were under great pressure from the European nation-states to finally allow the European arrest warrant to take effect. This is a prime example of the primacy of integration at the cost of material rule-of-law principles. It ended as one could expect with the motto: "Integration above all!" The second draft became law.

7 Braum, S., Europäisches Strafrecht im Fokus konfligierender Verfassungsmodelle, ZIS 2009, p. $419 \mathrm{ff}$.

8 Albrecht, P.-A., Die Normgenese des Europäischen Haftbefehlsgesetzes: Eine demokratietheoretische Depression in: Mit Recht für Menschenwürde und Verfassungsstaat, Festgabe für Burkhard Hirsch, 2006, p. 115ff. 


\section{Dominance of the executives}

The EU also has the same problems regarding the executive European cooperation in judicial and police matters as is the case within the nation-states. The "hour of the executive" has come in the EU with even fewer hindrances because at that level there are neither effective institutional nor individual aspects of legal protection. Those affected must seek this protection in their home country. Penal law is made supranationally, enforced supranationally, but the sentences are carried out in the home country by judges who are at a disadvantage due to their lack of information; that is, unless another EU state is quicker to use the European arrest warrant! The citizens are becoming objects of surveillance by the European executive without having adequate legal protection against it. In the informalized law of the EU, the law enforcer's loss of binding force is almost absolute. The police officers of Europol have immunity from criminal proceedings if they use illegal methods in their investigations. The executive informal deals made between one European office and another, and from there with the national offices, is becoming the European norm. The telephone is replacing rule-of-law procedures. Braum describes this as network penal law which is unfolding at the executive level without resistance as integrated EU law. ${ }^{9}$

\section{Four Reasons why Criminal Law Guided by Rule-of-law Principles may not be "Communitized"}

First Argument - Penal Law: Powerful and destructive legal coercion

The particularity of penal law lies in its function, which is to exercise powerful and usually destructive legal force: "From the first suspicion to the verdict and the carrying out of the sentence, penal law includes a discrediting label, a degrading judgment that threatens to destroy the essence of a person by destroying their dignity and freedoms." 10 These are the realities of daily legal life. No other state area of regulation has such a destructive potential. Because penal law reaches into the private sphere of the citizens that is protected by basic and human rights - at least potentially - this intervention requires a special democratic legitimation. ${ }^{11}$ The question of competency for this specific area of regulation of the destruction of freedom therefore presents itself very clearly: Is it a competency of the Union or of the member states?

This is not only about the legitimate question of the political power to regulate. It is also about the substance of penal law, in particular the question of the punishability and "which rules, for what purpose, and under which conditions we should be allowed to punish." 12 The community treaties give us no answer - not even the Treaty of Lisbon. The first and last answer will have to be given by the Basic Law of the Federal Republic of Germany. The normative framework for this is given in Article 23 of the Basic Law,

9 Braum (Fn. 6), p. 420.

10 Braum (Fn. 6), p. 418.

11 Ambos, K./Rackow, P., Erste Überlegungen zu den Konsequenzen des Lissabon-Urteils des BVerfG für das Europäische Strafrecht, ZIS 8/2009, p. 402.

12 Braum (Fn. 6), p. 421. 
which contains the conditions for the principle of conferral, must be materially sounded out. In the future, this will increasingly be the task of the national law-makers, but also of the EU organs and courts and, not least, of penology.

Second Argument - Systemic protection through penal law: A self-destructive task

It is an excessive demand on rule of law-based penal law to use it for the purpose of protecting the system. The result of this use is always a symbolic penal law for "governing from a distance," that is, ineffective and counter-productive for the construed rules of the system. And this is true as well for the EU policy of flanking economic unity with penal law.

\section{Example: Diffusiveness of the corpus delicti}

Directives take effect here which even their creators might not understand. What finally comes to the national legal systems are semantic mammoths which even jurists hardly understand, let alone the addressees of the laws. The corpus delicti of money laundering, insider dealings, or subsidy fraud contradict the legality principle, particularly in terms of certainty. ${ }^{13}$

If we look at the corpus delicti of money laundering (Sec. $261 \mathrm{StGB}$ ), we see that the wording is on the one hand complicated, but on the other hand there are hardly any specific criteria for criminal responsibility. Criminal defense lawyers feel the brunt of this when there are questions as to whether the acceptance of fees for which there is a suspicion of criminal background represents criminal money laundering or whether it is seen as normal for criminal defense if effective legal counsel is to continue to be guaranteed. ${ }^{14}$ The confusion of the construction of the directives can be seen in the diffuse implementation of the directives in national law.

Penal law is also characterized by a series of undetermined legal terms. Instead of requiring that the criminal carries out the crime, often only the abstract threat of a crime is sufficient for penal law to be put to use. So-called endangerment crimes - in traffic law, in criminal environmental law, or in economic criminal law - are shifting from the exception they once were to the norm. The result is that criminal liability is brought back to an earlier point in time, and thus the limitations to power are lifted; power which is inevitably linked with penal law.

\section{Penal law is not a social repair shop}

Penal law may pursue legal violations which are essential for the protection of individual freedom as injustices. For this, it must be able to have access to clear rule-of-law regulations in order to determine the nature of the injustice. These regulations must be gua-

13 Cf. here Federal Judge Thomas Fischer in the FAZ from October 17, 2002: „Die Bilanz der Geldwäscheverfolgung ist jämmerlich“.

14 Cf. here only BGH NJW 2001, 2891ff. and OLG Hamburg NJW 2000, 673ff. 
ranteed to suspects as essential elements of the rule-of-law state. That is what penal law can do. Nothing more. The criminal justice system and its normative basis cannot be a social repair shop - not at the European level, either. These excessive demands will destroy it. But for reasons of self-preservation, the EU must refrain from calling up penal law for assistance in European integration. The European arrest warrant showed: The principle of mutual recognition, an effective instrument of control in the economic system, degrades penal law to a method of maximum restriction of freedom.

Third Argument - Punishability as the "culture of freedom": A lack of a European consensus

Criminal policy at the European level is far from a definition of punishability. The actual core of peno-legal injustice has been lost. The proof of one-sided and selective criminal policy at the European level is the proposal of a partial harmonization of European penal law known as "Corpus Juris." 15 The term "Corpus Juris" is a presumption which at the same time documents the enormous self-confidence of a bureaucracy that desires to decisively control the penal law of the EU member states. What is the goal? The European Union desires to protect its budget. It tries to do this not through reform of an administrative structure which is vulnerable to financial controls but with the assistance of penal law. The intended partial harmonization includes crimes which are focused on finances and assets of the European Union. Fraud, corruption, and money laundering are material-legal reference objects for European criminal policy.

If one takes a closer look at the reform proposals, one can see the extent of the planned destruction of a penal law oriented on penal legality. If those constructing the Corpus Juris were to have their way, negligent fraud would be criminal, the punishability of the attempt would be extended so that money laundering and concealment of stolen goods are combined into one corpus delicti with hardly any criteria for responsibility. As a consequence of the European intervention in penal law, the corpus delicti of subsidy fraud has already been expanded to such as extent that any improper use of a subsidy can be punished with a criminal lawsuit. ${ }^{16}$ The power of the bureaucracy is therefore great: Whatever it declares to be the political goals of the subsidies in each individual case is backed up by penal law.

The national differences in realizing European legal principles are very large amongst the 27 individual member states. In all states, the project of "communitized penal law" must be reflected on, publicly explained, and European-wide principles of reference must be created before the project is begun. This is more than just an attempt at harmonization. If legal principles are harmonized amongst the states, then only political compromises arise which ensure a joint but necessarily low level of these principles. Freedom and human rights would then not be done justice. For the development of European penal law it is essential that a common understanding of legal principles be found. If a new social contract is to be negotiated, then a new, demanding, and general justification

15 Delmas-Marty, M. (Ed.), Corpus Juris der strafrechtlichen Regelungen zum Schutz der finanziellen Interessen der Europäischen Union, Ius Criminale, Tome 7, 1998.

16 Braum, S., Das „Corpus Juris“ - Legitimität, Erforderlichkeit und Machbarkeit, JZ 2000, p. 493ff. 
of legal principles and a consensus on punishability must be found which live up to the claim of protecting freedom to the greatest extent possible.

The jurisprudence of the European Court of Human Rights is oriented on punishability in its ruling against the members of the SED politbureau ${ }^{17}$ for their responsibility for the killings at the former German-German border. In this decision, at least the administration of the content of penal law can be seen. There is a penal law - that of human rights violations - which is recognizable for all those in political offices regardless of political system, time, or place. The idea of punishability well-known in Enlightenment philosophy is thus experiencing a renaissance.

As long as there is no consensus in Europe as to what belongs in the crime catalogue as punishable and what could be more appropriately and effectively be regulated by social methods of control, that is how long the debate about criminal policy on punishability and rule of law-based criminal legality in the national context will continue. The dilemma is not eliminated there either, but that is where the reforms are more appropriately democratically demanded, officially legislated, and - this is the hope - realized. At any rate: As long as rule of law-based criminal law is not effectively reestablished as the national level, it cannot be "communitized" at the European level. That would exponentialize national dilemmas.

The principle of legality (Art. 103 Para. 2 GG): A forgotten prescription

Germany's national jurisprudence hardly corrects this development currently. The Federal Constitutional Court and Federal Court of Justice repeatedly emphasize the great leeway that the law-makers have in formulating penal legislation, that is, they emphasize the unlimited authority over the contents of what is punishable. According to this, penal laws must be flexible enough in order to do justice at all times to the "complexity of life." 18 Undefined legal terms, which the vernacular dubs not inappropriately "rubber paragraphs" are indispensible. The core of the argumentation is that one should not focus too much on preciseness if penal law is to function in real life. What may be nicely written theoretically is not appropriate for the practice. In this practice, adherence to penal legality is seen as an unobtainable ideal, an ideal that you can easily forget when a citizen falls into the hands of penal law.

Another common argument is that the danger of power abuse is not very great in a democracy, and therefore the principle of legality does not need to have the same limiting effect as appeared necessary in the era of Enlightenment philosophy. Democratic criminal policy is more open and therefore does not need strict and inflexible rule-of-law boundaries.

Thus penal laws can be understood as the will of changing and sometimes coincidental majorities. There is no independent content but only the reflected will of the majority. But if penal law can take on any arbitrary content, then even in a democracy it is not safe from overshooting its mark. If everything is possible in penal law, then the democratic, rule-of-law character of penal law is constantly threatened from shifting into

17 ECHR NJW 2001, 3035ff. (Case Krenz and others).

18 Most recently BVerfGE 55, 144, 152. 
authoritarian forms of surveillance and punishment. Democracy is then only an empty shell in which the executive can take control of penal law, and penal legality is its loot.

Fourth Argument - Condition for rule of law-based criminal law: Basic reform of national democracy

This is now getting to the core of the problem. Before transferring the authority for penal law to the supranational level, the nation-states must begin reforms of their national democracies - a broad task.

The criterion for legitimacy of the process of forming a democratic will is, at least in the traditional nation-state, the will of the majority. In constitutional reality, this is formally sufficient. It is the typical political-cultural commonsense reference point within the 27 EU states. The principle of limited delegation authority is subject to the will of the majority - at least from the perspective of the EU organs. Meanwhile, the critique of the exclusively formal criteria for democracy is increasing. The demands are for more deliberative democracy, that is, more elements of participation in the framework of an interactive parliamentarianism. Deliberative democracy emphasizes the active participation of all citizens: First, this can be seen as participative democracy. This must produce the fertile ground for resonance in the political public which is necessary for legitimizing legislation. In Europe's democratic states, more and more emphasis is put on participation and not just observance. Procedures of self-legislation are being demanded where deliberative democracy can be seen. This means more active participation than just formal voting during elections. The constantly growing potential of non-voters makes the urgency of this concern clear.

For the special reasons of punishing, democratic legislation needs a deeper legitimacy than the mere will of the majority can currently give. What is recommended is that those creating penal legislation publicly justify their actions, that empirical experiences are examined, that foreign expertise is put to use, and especially that normative tenability and the consequences of legal projects are reflected upon. ${ }^{19}$ Whether this can be called the "application of practical rationality," however, currently remains only a hope. The demands on the law-makers are great. They would be well advised to limit the flood of legislation by means of reduction. That is the only way that a "culture of freedom" can develop out of penal law, and only such a material rule of law-based criminal law would be the basis or at least the reference point for a European "communitization."

\section{The Decision of the Federal Constitutional Court on the Treaty of Lisbon: A European Drumbeat}

The particularity of destructive legal coercion, the incapability of the rule of law-based criminal law for protecting the system, the lack of a consensus on punishability, and the lack of democratic participation are key points which appeared in the decision of the Federal Constitutional Court on June 30, 2009, on the constitutional basis of the Treaty of Lisbon. The Federal Constitutional Court contrasts the European Court of Justice's

19 Braum (Fn. 6), p. 422. 
purely instrumental understanding of penal law (that is, to always invoke all possible social purposes) with a sensible decision on the democratic legitimacy of penal law in the sense of a legal-ethical minimum. In this decision, one can see:

- a core penal law which is imbedded in

- European basic principles of rule-of-law enlightenment and

- comprehensive democratic legitimacy.

The creation of European penal law - which is also done through future majority decisions - by the EU organs will only be legitimate if

- serious enforcement efforts could be proven and

- these could only be overcome by the threat of punishment. ${ }^{20}$

Despite the "lack of boundaries for the competency title" in the Treaty of Lisbon, this makes possible a "sufficient starting point for an interpretation which is in line with the constitution." 21 The Federal Constitutional Court is centrally shutting down "democratic self-determination." This "is, however, affected in a particularly sensitive way when a legal community is hindered in deciding on the punishability of behaviors and imposing prison sentences according to its own moral concepts. This is especially true the more these moral concepts are tied to historical experiences, faith traditions, and other factors essential to the self-perception of the people and their community. This is why transferring the competency for penal legislation can only be permitted to a limited extent and, when expanding the catalogue of the areas of crime falling under the legislative competency of the Union, it is absolutely necessary to ensure that the requirements for an individual transfer of sovereignty are followed (Art. 23 Para. 1 Sent. 2 GG). The use of the dynamic blanket authorization according to Art. 83 Para. 1 and Para. 3 TFEU, 'depending on the development of crime' to expand the catalogue of particularly serious cross-border crimes equates to an expansion of the written competencies of the Union and is therefore subject to the reservation of statutory powers according to Art. 23 Para. 1 Sent. 2 GG)."22

A further interpretation topos is the peno-legal principle of guilt which the Federal Constitutional Court declared to be guaranteed in perpetuity:

"The competencies of the European Union in the area of the administration of criminal justice must in addition be interpreted in such a way that fulfills the requirements of the principle of guilt. Penal law is based on the principle of guilt. This assumes the individual responsibility of a person who can determine his own actions and, due to his free will, can differentiate between right and wrong. The protection of human dignity is underpinned by the belief that a person is an intellectual-moral being who is designed to determine his own fate and develop in freedom (cf. BverfGE $45,187<227>$ ). In the area of the administration of criminal law, Art. 1 Para. 1 GG determines the perception of the nature of the punishment and the relationship between guilt and atonement ( $c f$. BVerfGE 95, $96<140>$ ). The principle that every punishment requires guilt is based in the guarantee of human dignity in Art. 1 Para. $1 G G$ (cf. BVerfGE 57, $250<275>$; 80, $367<378>$; 90, $145<173>$ ). The principle of guilt belongs to the inaccessible constitutional identity according to Art. 79 Para.

20 BVerfGE 123, 267, 411.

21 BVerfGE 123, 267, 411ff.

22 BVerfGE 123, 267, 412. 
$3 G G$, which is also protected from encroachments by the supra-nationally used public authority. "23

This is a very clear statement on the rule-of-law development of the community - at least from the perspective of the German Federal Constitutional Court, which is bound to the German law-makers.

In the Treaty of Lisbon, the national parliaments are given an emergency brake through which, and now strengthened by the Federal Constitutional Court, the "communitization" has been made available for the parliaments to check. With this decision, European criminal policy and national law-makers have for the first time received a standard from the highest court for checking and justifying the process of communitization. In the future, the national parliament has access to a yardstick which can be used to create and apply standards. In addition, the public can be given understandable reasons for when and why peno-legal reactions of the EU law-makers can be called for.

Not only the ECJ faces serious conflicts of competency. In the future, both the national and international law-makers will have to look more closely at the question of who can best protect the individual from the unreasonable demands of state authority in a European community which is growing ever closer together.

The intensity of the academic and particularly political reasons to this decision make it clear that a power- and competency-limiting decision such as this from the highest German court was long overdue. In regular intervals, my Frankfurt colleagues and I attempted to make these constitutional contours clear to the expert public. ${ }^{24}$ In the area of public and civil law, the peno-legal particularities have not yet been adequately taken into consideration. The goal of integration predominates, especially at the economic and public-legal levels. Rule-of-law warnings are perceived as a hindrance to the legitimate goal of integration and rejected.

With my contribution "European Peno-Legal Space - A Nightmare?"25 and with my position on a "democracy theory depression" as a consequence of the "Norm Creation of the European Arrest Warrant" 26 I provoked rejections by this choice of words. But, besides academic provocation, what else can be done in the face of an overpowering movement towards integration at any price?

\section{After the Lisbon Decision of the Federal Constitutional Court}

\section{Strengthening the national parliaments' consultation rights}

German law-makers must learn anew how to deal with the European Union regarding peno-legal rights of sovereignty. The legal instruments are present, but they must also

23 BVerfGE 123, 267, 413.

24 Albrecht, P.-A./Braum, S., Defizite europäischer Strafrechtsentwicklung, KritV 1998, p. 460ff.; Albrecht, P.-A./Braum, S./Frankenberg, G./Günther, K./Naucke, W./Simitis, S., 11 Propositions toward the Development of Legal Foundations for European Criminal Law, KritV 2001, p. 269ff.; Albrecht, P.,-A., Europäische Infomalisierung des Strafrechts in: StV 2001, p. 69ff.;

25 Albrecht, P.-A., Europäischer Strafrechtsraum - ein Albtraum?, in: ZRP 2004, p. $1 \mathrm{ff}$.

26 Albrecht (Fn. 7), p. 115ff. 
be used. The experiences with the European arrest warrant show that the German legislation still has much to learn. The law-maker was almost relieved to give up the responsibility for the areas of social control dealing with sensitive aspects of basic rights in the process of the creation of the European arrest warrant legislation. The law-maker was almost in a hurry to get rid of the vexing question of extraditions which contradicted clear constitutional demands. The example of the European arrest warrant proves this in a paradigmatic manner. ${ }^{27}$ Although the Basic Law prescribes in Art. 16 Para. 2 that "no German may be extradited to a foreign country," this human right was suspended by the scratch of the law-makers' pen in 2004. The principles of legal certainty and protection for the reliance on existing law for Germans who might be extradited to EU states had to be clearly brought back to the law-makers' minds by the Federal Constitutional Court's decree of nullity in 2005. The constitutional law expert M. Herdegen was cited in the Frankfurter Allgemeine Zeitung with the words that Germany is creating the impression that it "wants to avoid anything that might protect the substance of basic rights." 28

There are already objections being brought up against constitutional law: De lege lata, it should not stand in the way of the harmonization and expansion of peno-legal controls. The constitutional court only strengthened parliamentary procedural law. There are already predictions of the diplomatic tumult that would arise if the "parliamentary emergency brake" is ever to be used, as a veto would "create bigger waves [in the European public] than the (merely temporary) reluctance to actively support a legal act." 29

The German parliament will also have to learn to deal with its new role as an alert controller of the principles of limited authority and material subsidiarity. There are now concrete constitutional criteria for evaluation, and the public is entitled to be allowed to participate in this debate of "communitization": These debates must be encouraged throughout Europe, and they must seek out new linguistic forms of communication, ${ }^{30}$ for example about education reforms at universities and in the judiciary. It can and must trust in a European public: "The ground for political resonance has been prepared for a long time: It comes from the European consciousness, from the injust experiences of the 20th century, from the European Enlightenment philosophy, from the daily encounters of Europeans who do not define themselves by their language or religion but through the joy of being able to encounter each other as free and equal people throughout Europe." 31

27 Albrecht (Fn. 7), p. 115ff.

28 FAZ from November 4, 2005.

29 Heger, M., Perspektiven des europäischen Strafrechts nach dem Vertrag von Lissabon, ZIS 8/2009, p. 414.

30 Albrecht/Braum/Frankenberg/Günther/Naucke/Simitis (Fn. 23), p. 269ff.; Albrecht, P.-A., Could an independent Judiciary be a Counterbalance to the Erosion of European Principles of Criminal Law? in Albrecht, P.-A./Thomas, J. (Ed.): Strengthen the Judiciary's Independence in Europe!, 2009, p. $19 \mathrm{ff}$.

31 Braum (Fn. 6), p. 425. 


\section{Guideposts of European peno-legal development: The primacy of human rights}

The process of European unification stands in contrast to the previous centuries of war and destruction as a blessing for the European nations and their citizens. In Germany, the realization of the European Union is a constitutional charge (Art. $23 \mathrm{GG}$ ), and that is a good thing. European integration is absolutely necessary - in many areas. But it can also encourage calamity if it is to be achieved at any price.

It creates disaster in penal law. Expansion, intensification, and the deconstruction of rule-of-law principles are the characteristics of the current state of penal law in its European framework. These characteristics stand in clear contrast to that which the European Convention on Human Rights seemed to desire for the future of a common European penal law in 1945: To push back the intervention of the state and bind the state's penal law to the responsibility of following democratic, rule-of-law principles in penal law. What was apparent in the European Convention on Human Rights for the penolegal tradition is now running alongside the current developments in European penal law. Both developments, one reacting to a massive experience of injustice, and the other to problems of a saturated welfare society, do not meet. One cannot avoid tracing the European framework for penal law back to its foundation in human rights. And once this is done, then almost everything which is now beginning to be done under the name of "European penal law" must be retracted. ${ }^{32}$

\section{European Penal Law as Penal Legality Guided by Principles - There is Hope}

\section{Expectations for European Integration: Institutionalized penal legality}

Europe has an important task: European integration is on the agenda. European integration also means constructively implementing the message of European Enlightenment as a common legacy.

- Indispensable, nonnegotiable principles of penal law

Penal law can only contribute in small part - if at all - to these efforts. It is based on a few indispensable principles that are not open to negotiation and which must be secured. With the background of its depressing experiences, for which especially Germany has a historical responsibility, Europe needs a penal law based on legality, which was the aim of European Enlightenment. The task of penology can be no less than that of reviving neglected or forgotten principles of European penal law or making them more practically manageable.

32 Albrecht/Braum (Fn. 5), p. $312 \mathrm{ff}$. 
- European penal law based on penal legality versus administrative sanction law

The European sanctions law as currently practiced without a broad theoretical foundation and created as an instrument for control and coercion for the economic interests of the European Union must be clearly differentiated from this penal law based on penal legality. Sanctions law in the technical sense for regulating economic crises may well find recognition as an instrument for intervention regulated by the rule-of-law. Unfortunately, the opposite trend can currently be observed. Current legal policies work on erasing this border between administrative sanctions law and penal law based on penal legality. This process buries penal law which is guided by principles.

\section{Expectations for a European Penal Law Based on Penal Legality: The Free Core of Penal Law}

- The demand: Core European penal law based on penal legality

Three constructional defects can be found in their entirety - and even more extensively - at the European level. As is the case with national penal law, European penal law will fail in the face of the demand to protect the system because a free penal law focused on the core of penal law cannot fulfill governance tasks. For this purpose it is an inadequate tool. The consequences are therefore:

- Demands for systemic protection break rule-of-law criminal law.

- Symbolic demands on criminal law abuse rule-of-law criminal law.

- These excessive demands will destroy the rule-of-law criminal justice system.

These three consequences are reason enough to lead a public, European-wide discussion about a penal law based on penal legality. Only a penal law freed from the excessive demands of governance will be able to protect the European principles of penal law from being destroyed in the tension between freedom and security. Only an unburdened criminal justice system, as a legacy of European Enlightenment, is capable of doing justice to these principles.

\section{Expectations for a Criminal Justice System of Penal Legality: Fair Trial and Rule- of-law Ideals}

- European-wide reforms of the national criminal justice systems

The European criminal justice systems need a courageous reform from top to bottom. Not only in Germany is there an urgent need for reform. As long as the national criminal justice systems do not start and implement these institutional and structural reforms, one can only expect the exponentiation of problems in a "communitarization." The Federal Constitutional Court wisely foresaw this in its Lisbon decision and administered justice clear-sightedly in regards to the guarantee in perpetuity found in the German constitution. For the rule-of-law structure of the criminal justice system, to which the police also belong if it is defined broadly, the following requirements are to be created: 
- European police

In the rule-of-law state, the police have preventive tasks to protect against threats and repressive tasks of law enforcement which are to be clearly defined. Only if intervention authority which distorts basic rights are transparent and can be reviewed at any time can public loyalty to the police institutions be expected. The European experiences with police-state terror speak for themselves and need no further justification. That is why the shift in the power balance in Europe in favor of operational intervention authority for the police in civil liberties of the citizens must be reversed. The boundary to repressive law enforcement must remain ascertainable and verifiable by the judiciary. Here, the state prosecutor's office has an important watchdog function.

\section{- European state prosecutor's offices}

The state prosecutor's office has an important task in the context of law enforcement. The law-maker may not overload the state prosecutor's office with irrelevant tasks to which it cannot come close to doing justice given its material and personnel resources. For crime prevention and for overcoming social risk situations, it is the worst possible actor. This inappropriate demand leads to the collapse of the essential tasks of investigation and legal control of the prosecuting body. The shift in function of the state prosecutor's office through informalization and executive law and the resulting shift from a prosecuting to an adjudication agency must be reversed. The state prosecutor's office has the task of law enforcement and presenting the suspicion in a legal form for the court proceedings. The constitutional state has set up a separate independent judiciary for determining the facts of the case and guilt. The state prosecutor's office, as a part of the executive branch, is excluded by the constitution from the judicial task of sanctioning. Overloading the state prosecutor's office with quasi-judicial power may flatter the reputation of the state prosecutors, but it is counter-productive for carrying out their actual job. The motto must be: Away from opportunity, Return to legality - European-wide, nationally and transnationally.

\section{- European criminal defense}

Criminal defense is a struggle in the rule-of-law state, not only for the accused and defendants, but particularly for the culture and the self-perception of the rule-of-law state. The marginalization of criminal defense through secret preliminary proceedings (system for special rights in anti-organized crime) and the attempt to harmonize the criminal defense's role using consensual forms of proceedings must be strictly objected to for principle rule-of-law reasons. The consequence is otherwise clear: The defense lawyer becomes a pastor and can only assist the client with good advice. 
- European autonomous and independent third power

Judicial independence is the basis of a functioning criminal justice system. This is the starting point for all reform efforts beginning with the legal education at the university. The careers of state prosecutors and judges should no longer be interchangeable. The roles are principally different and need institutionalized boundaries to independence. The judge is responsible for the judicial formality of the proceedings. In the control of legislative and executive power, the social control in the form of the constitutional checks and balances assigns the judiciary an important constitutional-political function. It ensures the creation of legal certainty and legal freedom. What is meant is the security of the citizens from state intervention and the freedom which allows individual freedom to be unfurled through the limitation of social power. The criminal justice system must always be conscious of this watchdog function for the protection of the elementary ruleof-law principles introduced here. The judiciary's loss of control, the loss of independence, and the loss of the judicial power entrusted to the courts by the Basic Law (Art. 92 GG) must be brought to an end. Otherwise the judiciary threatens to eliminate itself. This is especially true for a European third power which must be accessible to the citizens to serve to protect basic rights throughout Europe.

- Limits to absoluteness for legislative and executive in the judicature of the Federal Constitutional Court

A “communitarization" of Europe's criminal justice system assumes the acceptance of national standards of basic rule-of-law structures of police, state prosecutor's offices, courts, and penitentiaries. The German Federal Constitutional Court has protected an elementary basic right of the citizens in recent years. With every further step toward European integration with the background of Art. 79 Para. 3, Art. 20, and Art. 1 GG, the following decisions have been helpful in the necessary search for absolute boundaries which cannot be crossed in the area of penal law:

- BVerfGE 109, $313 f f .:$ Right to "core area of private life" - Decision on the largescale eavesdropping operation

- BVerfGE 109, $190 f f .:$ Unconstitutionality of the Bavarian and Saxony-Anhalt laws on accommodating a criminal ("retroactive preventive custody")

- BVerfGE 113, 348ff.: Unconstitutionality of the regulations on preventive telephone surveillance in the police law of Lower Saxony

- BVerfGE 115, $118 f f .:$ Prohibition of the "saving shootdown"-decision on the aviation security law

- BVerfGE 115, 320ff.: Restrictions on preventive police computer-aided searches for warrants in tension with the informational right to self-determination

- BVerfGE 120, $378 f f .:$ Constitutional limits to automated police collection of license plates for the comparison with outstanding warrants

- BVerfGE 120, $274 f f$.: Constitutional requirements for the permissibility of state access to information-technical systems ("online searches")

- BVerfGE 121, 1 ff. und 391ff.: Provisional directives on the limits on data retention 
- The Lisbon decision as an important milestone of European constitutional traditions

The Federal Constitutional Court took on the perspective of the "peno-legal proprium" in the Lisbon decision in the interest of the rule-of-law state. That is an important milestone on the path to a correctly understood "communitarization" which is not by any means rejected by penal law but must first be traced back to the constitutional necessities and possibilities. The link to the guarantee of perpetuity makes it even clearer that the law-makers do not have access to everything which penal law objects to. There are boundaries to absoluteness which come before the written constitution and which have their continual legitimacy in the historical experiences with state and state-supported injustice. It can be hoped that this peno-legal path will be understood in the other areas of law. In the future, penal law cannot focus on European integration at any price but on integration which adequately takes into account the material rule-of-law principles as a legacy of European Enlightenment.

\section{Principles of a rule of law-based Criminal Law}

- Program for a European rule-of-law state with peno-legal law-making competencies Despite all ambivalences, European legal policies can be activated to fulfill an informative role:

It must be based on the fundament of constitutionalized freedom - on the

- principle of penal legality.

It must be based on the limitation of the state's punishing power with the assistance of the

- principle of guilt.

It must be based on the legal limitations to the state's use of power-on the

- principle of proportionality.

It must be based on a limitation of state arbitrariness by the

- principle of mandatory prosecution.

It must be based on the guarantee of public penal law, the

- principle of ex officio (public criminal justice system).

And it must be based on the foundation of free criminal proceedings, the

- principle of a fair trial as safeguard for a due process.

That is the legacy of the European Enlightenment which Europe can be proud of. 